\title{
Accounting
}

\section{Determinants of corporate social disclosure in Saudi Arabia: The role of social values and IFRS convergence}

\author{
Mohammed AIShetwi ${ }^{a^{*}}$
}

aQ Qassim University, Saudi Arabia

\begin{tabular}{l}
\hline C H R O N I C L E \\
\hline Article history: \\
Received: April 18, 2021 \\
Received in revised format: \\
April 212021 \\
Accepted: April 22, 2021 \\
Available online: \\
April 22, 2021 \\
\hline Keywords: \\
CSD \\
Corporate social responsibilities \\
IFRS \\
Saudi Arabia \\
Social values
\end{tabular}

\section{Introduction}

Legitimacy theory contends that a firm's success is dependent on the acceptance that it receives from its stakeholders (Frynas \& Yamahaki, 2016). According to this view, an interdependence relationship should be recognized between a firm and its stakeholders, implying that the firm shall establish its objectives consistent with its stakeholders' claims. However, recent trends in the global business environment indicate that a firm's strategic objectives are formalized based on both shareholder interest and stakeholder's claims (Igwe, Ituma, \& Madichie, 2018). The recent movement reflects increased concern for reporting social activities that a firm extends toward its society such as ensuring a good work setting, improving environmental practices, and dealing responsibly with customers and the community. Information on the social activities of a firm is conveyed by means of Corporate Social Disclosure (CSD). It has been suggested that disclosing non-financial information together with financial information could increase the opportunities for a firm's success (Smith, Adhikari, \& Tondkar, 2005). In practice, CSD is mostly used as a strategic goal to ensure conformity with a society's needs, thereby increasing a firm's legitimacy and enhancing its chances of survival within its society (Fifka, 2013; Weerathunga, Xiaofang, Nurunnabi, Kulathunga, \& Swarnapli, 2020). A practical illustration of the importance of CSD can be seen in the action of the London Stock Exchange requiring all listed firms to provide information on their environment, employees, and community. In Saudi Arabia, the Capital Market Authority (CMA) issued a guiding article (No. 87) of CG regulation suggesting that Saudi listed firms should establish a policy by which the firms could ensure that their objectives are consistent with development of the community (CG regulation, 2006).

\footnotetext{
* Corresponding author.

E-mail address: alshetwi@qu.edu.sa (M. AlShetwi)
} 
In addition, regulations have been introduced across the world indicating the importance of CSD practices, including the UN's Global Compact Principle, Global Reporting Initiative (GRI), and ISO 26000 Guidance for Social Responsibility. These further emphasize the importance of incorporating CSD in the reporting system to improve a firm's value. In summary, it should be noted that CSD is included in a firm's economic objectives, and thus it can be assumed to contribute to a firm's profit. Meanwhile, adoption of the IFRS has spread in the global business environment. Reflecting on changes in the financial disclosure environment around the world, Weerathunga et al. (2020) reported that more than 140 countries have moved to replace the local standards by the IFRS. For instance, Saudi Arabia converted to IFRSs starting from 2017. Indeed, IFRSs improved the transparency of financial statements by providing all important information that assists investors to make good investment decisions (Zeghal, Chtourou \& Fourati, 2012). In addition, IFRSs improve the disclosure environment (Smith, Gouldman, \& Tondkar, 2014) and present more information than that required by local accounting standards (Hsu \& Chen, 2020). Studies have shown that the interaction of the IFRS and CSD can lead to improved transparency in financial reporting (Bouten, Everaert, Liedekerke, Moor, \& Christiaens, 2011; Hsu \& Chen, 2020) and enhances a firm's visibility, thereby promoting and attracting foreign investment (Hsu and Chen, 2020; Weerathunga et al., 2020). Other studies have revealed that CSD is used together with mandatory disclosure as a means to enhance the competitive advantage of firms (Ali, Frynas, \& Mahmood, 2017; Fifka, 2013), increase a firm's value (Weerathunga et al., 2020), and to help evaluate a firm's stock prices (Avwokeni, 2016). From the perspective of theory, there are two competing views explaining the interaction between IFRS and CSD in terms of their impact on the disclosure mechanism. Both views are based on the idea that legal origins are considered to be the drivers for the interaction of IFRS and CSD (Smith et al., 2014; Xi \& Yang, 2016; Weerathunga et al., 2020). However, the legal basis for the legal origin model affecting the disclosure environment differs, with one view proposing the common law as the basis and the other proposing a code law model. In one view, if a firm is domiciled in common law countries (such as UK and Australia), the manager would be more interested in shareholders' claims, since they are pushed by the regulations that are primarily concentrated on providing information for the market's needs. Thus, the shareholder-oriented model prevails in such an institutional structure (Ali et al., 2017; Smith et al., 2014). However, the change in disclosure environment brought about by the adoption of IFRS will encourage managers to increase CSD to provide incremental disclosure meant for the existing mandatory disclosure system (IFRS). In such a situation, the disclosure mechanism is shown as a shift from a shareholderoriented to a stakeholder-oriented model in common law countries during the IFRS convergence (Smith et al., 2014). In contrast, countries having a code law system (like France and Germany) adopt a stakeholder- oriented model in which disclosure is used primarily to serve the stakeholders. When adopting IFRS in these countries, managers would be more concerned about fulfilling the requirements of IFRS and, therefore, their efforts are focused on complying with IFRS requirements rather than exhibiting corporate social responsibility activities. Thus, the disclosure mechanism in such a setting will be shown as a shift from a stakeholder-oriented to a shareholder-oriented model in the post-IFRS adoption period (Smith et al., 2014).

When evaluating the situation in Saudi Arabia, it has to be recognized that the legal system is characterized by unique features that are different from those found in the two systems mentioned (i.e. common and code law systems). Saudi Arabia derives its regulations from Islamic principles that depend heavily on two specific sources: the Holy Qur'an and the directions of Prophet Mohammed. In other words, all regulations in Saudi Arabia should be established according to Islamic law, including those relating to business aspects (Basic Law of Governance, 1992; Issa, 2017). In fact, Islamic principles incorporate motivations for kinship and brother-ship behaviors and teach their followers to be concerned about the community, environment, laborers, and customers (Khan, Al-Maimani, \& Al-Yafi, 2013). Therefore, a firm should deal responsibly using Islamic principles, and react to the beliefs and values of its society through the CSD to present its contribution to its society (Smith et al., 2005). In such a setting that exhibits strong conformity to the values of the society, it is expected that firms tend to establish CSD as a strategic objective in order to be legitimized and survive, and therefore managers will pay more attention to CSD even while they are under pressure to comply with IFRS requirements. In other words, the event of converting to the IFRS might not change managers' incentive to introduce CSD because CSD is motivated by societal values rather than any change in the financial disclosure environment.

The current study is based on the argument that a disclosure system as applied in common law and code law might not work in countries that follow strict conformity to social values, such as Saudi Arabia. In other words, the CSD-IFRS disclosure mechanism might work differently in environments that exhibit strong adherence to social values. This identifies a gap existing in prior studies concerning this issue, as most studies have been carried out in countries having either a shareholder-stakeholder orientation model. Considering the fact that firms domiciled in countries that strongly adhere to societal values should harmonize their activities with the society's needs in order to be legitimized and survive, and investigation of the CSD determinants in such a setting is warranted. Thus, this study aims to fill this gap and investigate whether CSD is affected by IFRS convergence or by social value in a country - Saudi Arabia - that has strict societal norms. Using a sample of 292 Saudi manufacturing and utilities firms listed in the Saudi Capital Market (TADAWL) over the period 2015-2019, this study finds that the change in the financial disclosure environment through IFRS convergence is not related to the CSD of the Saudi manufacturing and utilities firms in the sample. On the other hand, social values, modeled by adopting CSD as a strategic objective, is significantly related to CSD, indicating the effect of social values on the CSD of firms domiciled in countries having strong conformity to societal norms. This result provides evidence supporting the view that CSD is affected by social values rather than the change in the financial 
disclosure environment. In this way, the current study extends the work of prior studies that investigated the determinants of CSD, as it adds different insights on this issue from a country that exhibits strong conformity to its societal values (Saudi Arabia).

Unlike the studies of Smith et al. (2014) and Weerathunga et al. (2020), this study examines not only the IFRS convergence but also the effect of social values on CSD. It focuses on whether CSD differs among countries depending on institutional rule as modeled by social values. Contributing to methodology, the current study adopts the use of CSD as a strategic objective as a measurement for modeling the effect of social value on CSD. Further, the current study is an original study exploring this issue in countries that exhibit strong conformity to social values. For this reason, the results of this study are important for firms that intend to invest in countries having more concern for social values, suggesting that they should establish CSD as a strategic objective in order to be legitimized and survive in the longer term.

\section{Literature and Hypothesis Development}

Many theories have been used to explain the determinants of CSD. One of these theories is stakeholder theory that is used widely by researchers to explain the management-stakeholder relationship concerning CSD. As developed by Donaldson \& Preston (1995), this theory suggests that managers should keep a good relationship with firms' stakeholders, including their suppliers, customers, employees, community, and other stakeholders. According to this view, three attributes are assumed to be the most important factors affecting the management-stakeholder relationship concerning CSD: power, urgency, and legitimacy (Frynas \& Yamahaki, 2016; Smith et al., 2005). Power refers to the ability of stakeholders to enforce their claims; while, legitimacy reflects societal claims that firms need to conform with in order to be legitimized. Finally, urgency implies that stakeholders' claims are considered something critical and highly important, and therefore they should be a priority. In fact, management's reaction to stakeholders' claims depends on the extent of these three attributes. For example, power will be a very important attribute when firms' stakeholders hold the critical resources that firms need (Smith et al., 2005). Therefore, stakeholders might exercise pressure on the management to achieve their claims. For instance, if stakeholders' claims include ensuring the development of community and improving environmental practices, firms tend to increase their corporate social responsibilities activities on these claims as a result of power imposed by the stakeholders. As a consequence, the increase in corporate social responsibilities activities will lead to an increase in CSD as a means of conveying the firms' response to stakeholders' claims. In addition, adoption of IFRS obliges management to respond to the IFRS requirement. The interaction between IFRS and CSD calls for more disclosure and in turn enhances the transparency of firms' reporting (Bouten et al., 2011; Hsu \& Chen, 2020). On the other hand, managers tend to combine CSD together with IFRS in order to increase the visibility of the firm and therefore attract investment (Weerathunga et al., 2020). In this context, Hsu \& Chen (2020) contended that firms react to the IFRS requirement by increasing CSD. IFRS undoubtedly provides investors and other stakeholders with high quality reporting (Barth, Landsman, \& Lang, 2008), and therefore increases stakeholder confidence in CSD (Francis, Nanda, \& Olsson, 2008). Studies contend that the interaction between IFRS and CSD can be explained by two competing views (Smith et al., 2014; Xi \& Yang, 2016; Weerathunga et al., 2020). These two views are based on the premise that legal origins are the drivers of the interaction between IFRS and CSD; specifically, whether a firm is domiciled in a country governed by common law or one where code law prevails.

If a firm is domiciled in a common law country (such as the UK or Australia), the manager would be more interested in shareholders' claims, since they are pushed by regulations that are primarily concentrated on providing information for the market needs. Thus, the shareholder orientation model prevails in such a setting. The change in disclosure environment brought about by the adoption of IFRS will encourage managers to increase CSD to provide incremental information for the existing mandatory disclosure system (IFRS). Therefore, after IFRS convergence, managers are likely to focus on the stakeholders' claims rather than shareholders' needs that have already been met by the mandatory disclosure system. In such a situation, CSD is used as complementary to IFRS implying that the IFRS convergence will lead to increased CSD. The literature provides evidence supporting the complementary proposition of the interaction of IFRS and CSD (Ali et al., 2017; Avwokeni, 2016; Smith et al, 2014; Weerathunga et al., 2020). In contrast, countries having a code law system (like France and Germany) adopt a stakeholder- oriented model in which disclosure is used primarily to serve the stakeholders. When these countries convert to IFRS, managers would be more likely to be concerned with fulfilling the IRFS requirements than with providing information on corporate social responsibilities activities. In such a case, it is expected that the CSD level will actually decline as a result of adopting the IFRS, since all efforts are dedicated to complying with the IFRS requirements. Thus, the IFRS may be used as a substitute for CSD in code law countries (Consoni \& Colauto, 2016; Smith et al., 2014), implying that the adoption of IFRS will reduce the level of CSD content. The literature provides some evidence to support this view: for example, Smith et al. (2014) found that IFRS convergence did not lead to an increased level of CSD in code law countries. In fact, only a few studies concerning the interaction of IFRS convergence and CSD have been carried out. The study by Smith et al. (2014) is among a few studies in this area that examined the impact of IFRS adoption on CSD based on stakeholder theory. This study documented that firms domiciled in common law countries (i.e. shareholder orientation model) reported higher CSD after adopting IFRS; they also found that firms domiciled in code law countries (i.e. stakeholder orientation model) reported no change in the CSD following IFRS convergence. They suggested that the interaction of IFRS and CSD is dependent on the shareholder-stakeholder 
orientation model (i.e. whether firms are domiciled in common law or code law countries). Weerathunga et al.'s (2020) study also examined the effect of IFRS convergence on CSD. The result showed that CSD improved in firms adopting IFRS, suggesting that IFRS can have a significant impact on CSD. The study undertaken by Avwokeni (2016) examining the interaction of IFRS and CSD also found that CSD improved as a result of IFRS convergence. This result indicates that CSD served as a complement to the compulsory financial disclosure (i.e. IFRS). To summarize, in common law countries that adopt a shareholder-orientation model, espousing IFRS will be associated with little change in the pre-existing disclosure environment, thus leading to an increase in CSD as a complementary means of enhancing disclosure. Meanwhile, in code law countries that adopt a stakeholder orientation model, IFRS convergence brings about significant change in the disclosure environment since it requires more information to be disclosed than required by the pre-existing local standards, thereby leading to higher mandatory disclosure (IFRS). With more emphasis on the new mandatory disclosures, less attention is given to CSD.

The above discussion provides support for the proposition that change in the disclosure environment brought about by the IFRS convergence is an important factor affecting CSD. Since Saudi Arabia adopted IFRS in 2017, convergence with IFRS requirements might modify the incentives of managers toward CSD in the country. Thus, the first hypothesis of this study is developed in the alternative form as follows:

\section{$\mathrm{H}_{1}$ : There is a relationship between CSD and the IFRS convergence in the corporate sector of Saudi Arabia.}

However, CSD can also be explained by legitimacy theory. Advocates of this view argue that a firm engages in a contract with the society in which it is embedded (Frynas \& Yamahaki, 2016). The social contract between the firm and its society requires that the firm should formulize its objectives in line with the society's values and norms. In fact, the management-stakeholder model is based on the extent of conformity to social values. As noted by Smith et al., (2005), managers in countries that exhibit strong conformity to societal values tend to give more attention to the society's values in order to be legitimized and continue to survive. Unless a firm works to align its objectives consistently with the society's objectives, its operation will be under risk. For example, the firm may encounter penalties in the form of product boycotts or a decline in its sales, resulting in loss of its reputation and identity. In recognition of these potential consequences, a firm in such a setting tends to develop a strategic plan for its CSR activities in order to prosper.

In the case of Saudi Arabia, it is observed that Islamic law dominates all aspects of life, including those related to business acts (Basic Law of Governance, 1992; Issa, 2017). Islam teaches its followers to act responsibly towards their society (Khan et al., 2013). Thus, Islamic principles are considered to be a motivation for CSR, thereby leading to greater CSD in Islamic countries. Again, this emphasizes the importance of social values on CSD. In such a setting, it is expected that a firm will establish CSD as a strategic objective to increase its legitimacy and survival prospects and gain the benefits from enhanced reputation and, consequently, a higher market valuation.

Based on the above line of reasoning, the current study proposes that social value, as modeled by adopting CSD as a strategic objective, is an important factor affecting the incentives of managers toward adopting CSD in Saudi Arabia. Thus, the second hypothesis of this study is developed in the alternative form as follows:

\section{$\mathrm{H}_{2}$ : There is a relationship between CSD and social value in the corporate sector of Saudi Arabia.}

\section{Research Design}

\subsection{Sample}

The sample of this study comprises 292 Saudi manufacturing and utilities firms listed in TADAWL during the period of 20152019. Cement and Chemical firms are categorized as manufacturing firms based on the TADAWL classification. The old classification of TADAWL is used in order to ensure comparability of the selected firms over the whole five-year period. Since a wide range of stakeholders are affected by the operations of manufacturing and utilities firms, the sample is restricted to these types of firms. In addition, this procedure (i.e. selecting environmentally sensitive industry) is also a norm for prior studies on this issue (Bouten et al., 2011; Smith et al., 2005). The sample size of this study represents more than one-third of Saudi nonfinancial firms listed in TADAWL, which is sufficiently large to conduct research. The companies' annual reports are used to collect data since other reports, such as sustainability reports, corporate social responsibility reports, and other corporate social responsibilities reports, are seldom prepared by the Saudi corporate sector.

\subsection{Variables and Model}

\subsubsection{The Dependent Variable}

Corporate Social Disclosure (CSD) is the dependent variable of this study. Consistent with prior studies (Francis et al., 2008; Reverte, 2009), a self- constructed measure is used to define the CSD variable. As suggested by Francis et al. (2008), the selfconstructed measure provides more confidence that measurement will capture the concept more precisely. Following Smith et 
al. (2005), this study uses a self-constructed measure based on ISO 26000 to identify the dimensions representing CSD. Accordingly, four dimensions are adopted which include: labor practices, the development of the community, customer issues, and the environment. A dichotomous unweighted approach is used to measure the dimensions by assigning 1 if the dimension is disclosed, and 0 otherwise (Smith et al., 2014). This process yielded a measure ranging from 0 to 4 . In order to obtain the percentage of CSD in each firm, the $\sum$ of actual disclosure for each firm is divided by the maximum number of checklist items (Consoni \& Colauto, 2016). The CSD items in each dimension are gathered manually instead of using software content analysis because the annual reports of Saudi listed firms are not available in English.

\subsubsection{The independent variables}

Two independent variables are adopted in this study: IFRS, and social value. IFRS as denoted by (IFRS) captures the effect of IFRS convergence on CSD. If the IFRS coefficient is positive, the IFRS convergence will be associated with increased CSD. Social value as measured by using CSD as a strategic objective (SDSTRATG) captures the effect of social value on CSD. A dummy variable is used to measure this variable, taking 1 if a firm has a CSD strategic objective, and 0 otherwise. A positive sign for SDSTRATG indicates that a firm incorporating CSD in its strategy has a higher CSD level, implying that social value is an important factor affecting CSD.

\subsubsection{Control Variables}

Consistent with prior studies (Reverte, 2009; Weerathunga et al., 2020), the current study includes the following variables in the regression model. First, the firm's size (SIZE): captures the effect of firm size on CSD, proposing that the relationship between size and CSD is positive. This variable is measured by the natural logarithm of total assets. Second, Return On Asset (ROA): this captures the effect of firm profitability on CSD. Consistent with prior studies, the current study expects a positive relationship between ROA and CSD. ROA is measured by dividing the profit before tax on the total asset. Third, Leverage (LEV) is obtained by dividing liabilities on the total asset. Since prior studies have produced inconsistent results regarding the relationship between leverage and CSD, the current study does not propose any direction of the effect of leverage on CSD. Fourth, Firm Age (AGE): refers to the effect of a firm's age on the CSD: it is proposed that longer-established firms are more likely to disclose more information in CSD. The current study uses the listing age of the firm to measure the age. Fifth, Audit Quality (BIG 4): prior studies have suggested that firms that engage big 4 auditors are more likely to have higher CSD. This variable is measured by using a dummy variable, taking 1 if the firm engages big 4 auditors and 0 otherwise. Sixth, Board Independence (B-IND): this refers to the percentage of independent board members. The current study, consistent with prior studies, expects a positive relationship between the board independence and CSD.

3.2.4 Model

$$
C S D_{i t}=\dot{\alpha}+\widehat{\beta}_{1} I F R S_{i t}+\widehat{\beta}_{2} \operatorname{SDSTRATG}_{i t}+\widehat{\beta}_{3} S I Z E_{i t}+\widehat{\beta}_{4} R O A_{i t}+\widehat{\beta}_{5} L E V_{i t}+\widehat{\beta}_{6} A G E_{i t}+\widehat{\beta}_{7} B I G 4_{i t}+\widehat{\beta}_{8} B-I N D_{i t}+e_{i t}
$$

where, the CSD is the percentage of CSD in each firm and the remaining variables are as presented above.

\section{Results}

\subsection{Descriptive Analysis}

Table 1 presents the statistical information for the variables included in the model.

Table 1

Descriptive Statistics

\begin{tabular}{|c|c|c|c|c|c|}
\hline \multicolumn{6}{|c|}{ Panel A: descriptive statistics for continuous variables } \\
\hline Variable & Mean & Median & Max & Min & SD \\
\hline CSD & .73 & .75 & 1 & 0 & .02 \\
\hline SIZE & 13.3 & 14.3 & 19.9 & 5.12 & .21 \\
\hline $\mathrm{ROA}$ & .04 & .036 & .28 & -.62 & .01 \\
\hline LEV & .40 & .39 & 1 & .01 & .014 \\
\hline AGE & 19.9 & 12 & 50 & 1 & .89 \\
\hline B-IND & .49 & .44 & 1 & .14 & .01 \\
\hline \multicolumn{6}{|c|}{ Panel B: descriptive statistics for non-continuous variables } \\
\hline Variable & Ratio & & & & \\
\hline SDSTRATEG & 42.1 & & & & \\
\hline
\end{tabular}

The mean value of the CSD is .73 indicating that the Saudi manufacturing and utilities firms tend to disclose more information on the CSD. This is because they are more sensitive to stakeholders' claims on social issues than other firms (Smith et al., 2005). Fig. 1 and 2 provide more details on the level of CSD stratified by the years and the type of CSD. The results, as presented in 
Figure 1 show that the CSD on labour issues achieved the highest percentage score (84.6), followed by community, and customers. Both community and customers achieved a similar percentage score ( 72.3 and 72 respectively), while the lowest percentage score was CSD on environment practices (62). This indicates that Saudi manufacturing and utilities firms give more attention to their workers, responding to recent developments in the legal system regarding employees. However, the result calls for improvement in the rule related to environmental practices in Saudi manufacturing and utilities firms. Figure 2 shows that the year of 2018 showed the highest percentage score for CSD (.75); in contrast, the year of 2015 showed the lowest percentage score for CSD (.68). The percentages of CSD in 2016, 2017, and 2019 were .74, .72, .73 respectively, Overall, the results reflect that the focus of attention on CSD by Saudi manufacturing and utilities firms has been increasing.

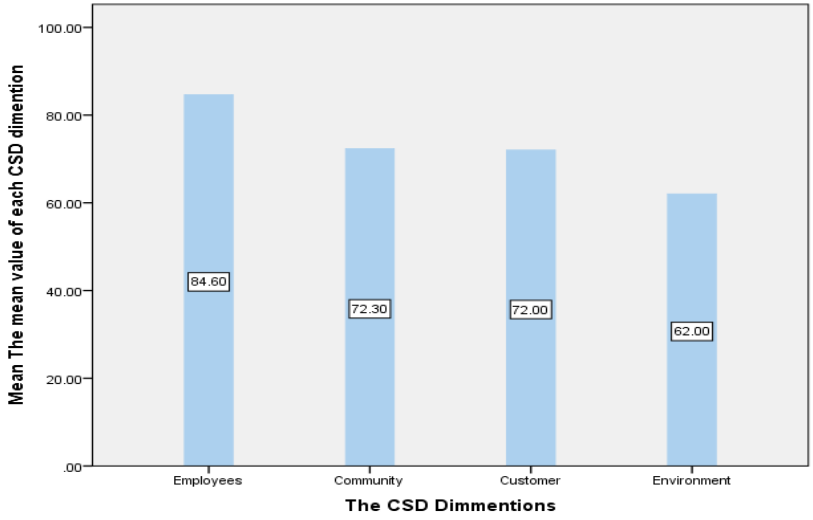

Fig 1. The mean values of CSD dimensions

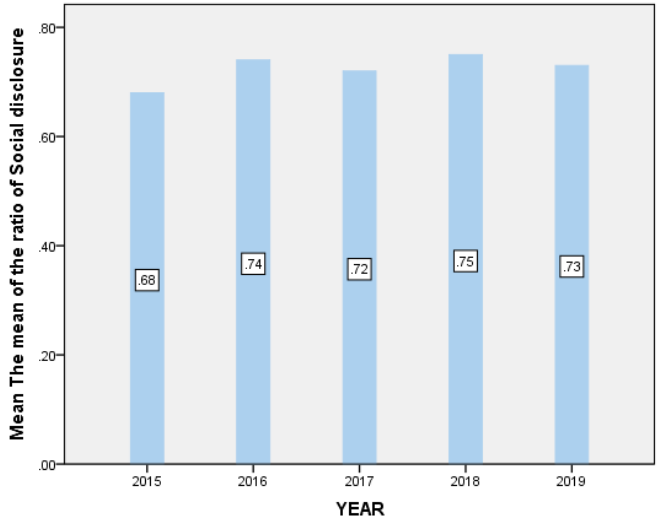

Fig. 2. The mean values of CSD by years

The descriptive statistics for explanatory variables, as presented in Table 1, shows that about 42.1 percent of Saudi manufacturing and utilities firms established CSD as a strategic objective compared to a majority (57.9\%) of those firms that do not have a CSD strategic objective. This result implies that only a moderate number of Saudi manufacturing and utilities firms recognize the role of CSD in enhancing the value of firms.

\subsection{Regression Result and interpretation}

The result of Pearson correlation reveals that the problem of multicollinearity should not be a serious concern among the variables, with correlation coefficients not exceeding .5, and the variance inflation factor (VIF) scores all less than ten (Hair, Anderson, Black, Baben, \& Tatham, 2006).

\section{Table 2}

Regression results for CSD

\begin{tabular}{|c|c|c|c|c|}
\hline \multicolumn{5}{|c|}{$C S D_{i t}=\dot{\alpha}+\widehat{\beta}_{1} I F R S_{i t}+\widehat{\beta}_{2}$ SDSTRATG $_{i t}+\widehat{\beta}_{3} S I Z E_{i t}+\widehat{\beta}_{4} R O A_{i t}+\widehat{\beta}_{5} L E V_{i t}+\widehat{\beta}_{6} A G E_{i t}+\widehat{\beta}_{7} B I G 4_{i t}+\widehat{\beta}_{8} B-I N D_{i t}+e_{i t}$} \\
\hline Variables & $\boldsymbol{B}$ & $V I F$ & t-value & p-value* \\
\hline Intercept & .378 & & 4.1 & $.000^{*}$ \\
\hline$I F R S$ & .012 & 1.60 & .30 & .766 \\
\hline SDSTRATG & .110 & 1.17 & 3.21 & $.001^{*}$ \\
\hline$S I Z E$ & .013 & 1.55 & 2.40 & $.017^{*}$ \\
\hline$R O A$ & .626 & 1.35 & 2.96 & $.003^{*}$ \\
\hline$L E V$ & .219 & 1.27 & 2.91 & $.004^{*}$ \\
\hline$A G E$ & .003 & 1.06 & 3.19 & $.002^{*}$ \\
\hline BIG4 & .05 & 1.25 & 1.33 & 0.184 \\
\hline$I N D$ & -.155 & 1.05 & -1.53 & .128 \\
\hline$R^{2}$ & .190 & & & \\
\hline$F$-ratio & 8.31 & & .000 & \\
\hline
\end{tabular}

*p-values represent one-tailed tests when direction of coefficient is consistent with expectations.

Variables are as defined in model specification in the methodology section.

Table 2 shows the results of the regression analysis used to test the hypotheses of this study. The results revealed that the coefficient of IFRS variable was not significant at the five percent level (.77) implying that IFRS convergence is not related to CSD of Saudi manufacturing and utilities firms. In other words, firms included in the sample did not respond to IFRS convergence in terms of improving the disclosure level beyond that needed to comply with the IFRS requirements. Thus, the first hypothesis of this study is not supported. However, the coefficient of SDSTRATG was significant at one percent level ( $\mathrm{p}=$ .001 ) implying that firms that adopt CSD as a strategic objective show more information on corporate social responsibilities compared to those did not establish CSD as a strategic objective. Thus, the second hypothesis is supported. 
Overall, the results suggest that social values as modeled by using CSD as a strategic objective explain the increase in CSD in countries, like Saudi Arabia, that exhibit strong conformity to societal values. In other words, firms focus on CSD to convey information on their corporate social responsibilities activities such as improving working conditions, ensuring good relationships with community and customers, and improving environmental practices, in order to be accepted by the society around them. This result is in line with Smith et al. (2005) who found that social values are identified as one important determinant of CSD in countries with a strong concern for societal values. Collectively, these results provide evidence supporting the view that CSD is affected by social values rather than a change in the financial disclosure environment.

\subsection{Sensitivity test}

The current study includes several tests to confirm the initial results. An independent t-test sample is used to compare the mean values of CSD between firms having a CSD strategic objective with those not having a CSD strategic objective. Specifically, the aim of this analysis is to determine whether there is a difference between the two sets of groups. The result, as presented in Table 3, shows that the mean value of CSD of firms having a CSD strategic objective is significantly higher than those that do not have a CSD strategic objective $(\mathrm{p}=.003)$, where the mean value of the CSD of firms that have a CSD strategic objective is .85 compared to .55 for firms that do not have a CSD strategic objective. The magnitude of this difference between the two sets of firms is relatively moderate $\left(\mathrm{Eta}^{2}=.03\right)$ based on criteria suggested by Cohen (1988). According to Cohen $(1988)$, if Eta ${ }^{2}=$ .01 , the effect size is small, moderate if $\mathrm{Eta}^{2}=.06$, and large if $\mathrm{Eta}^{2}=.14$.

\section{Table 3}

Independent Samples Test

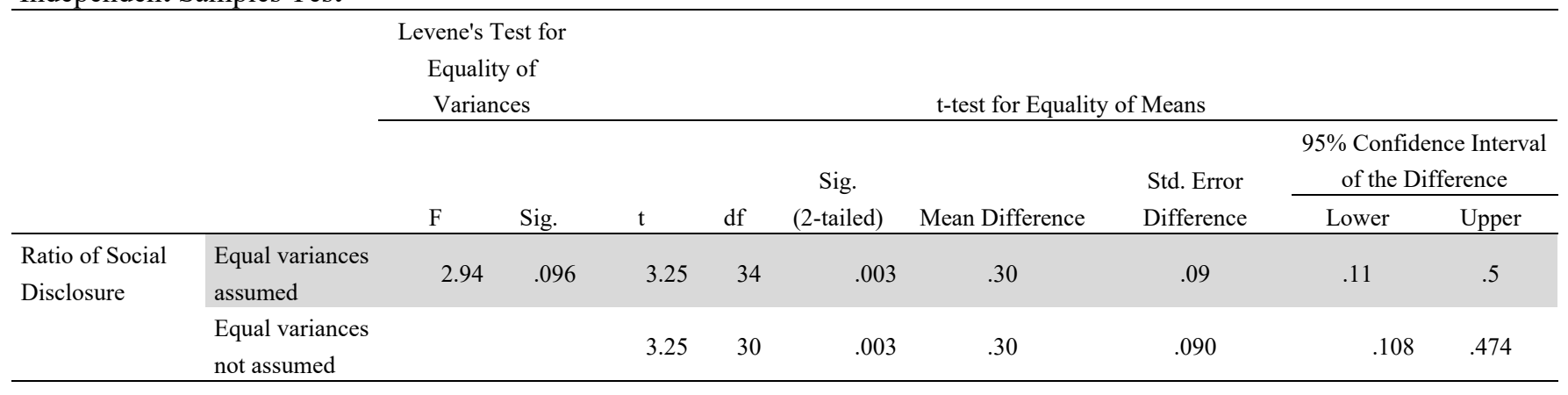

The second additional analysis is used to compare the CSD before and after IFRS convergence. The aim of this test is to check the initial result that revealed the IFRS has no impact on CSD. (i.e. Saudi manufacturing and utilities firms did not respond to the change in financial disclosure environment - IFRS convergence - by modifying the CSD). Table 4 summarizes the result of the paired sample t-test. The analysis yielded a small $t$ value of 1.27 , insignificant at the five per cent level ( $p=.21$ ), suggesting that the IFRS convergence did not lead to any effect on CSD in Saudi manufacturing and utilities firms.

Table 4

Paired Samples Test

\begin{tabular}{|c|c|c|c|c|c|c|c|c|c|}
\hline & & \multicolumn{5}{|c|}{ Paired Differences } & \multirow[b]{4}{*}{$\mathrm{t}$} & \multirow[b]{4}{*}{ df } & \multirow[b]{4}{*}{ Sig. (2-tailed) } \\
\hline & & \multirow[b]{3}{*}{ Mean } & \multirow[b]{3}{*}{ Std. Deviation } & \multicolumn{3}{|c|}{$95 \%$ Confidence Interval of the } & & & \\
\hline & & & & \multirow{2}{*}{$\begin{array}{c}\text { Std. Error } \\
\text { Mean }\end{array}$} & \multicolumn{2}{|c|}{ Difference } & & & \\
\hline & & & & & Lower & Upper & & & \\
\hline Pair 1 & $\begin{array}{l}\text { The mean of pre IFRS \& } \\
\text { post IFRS }\end{array}$ & -.034 & .19903 & .02684 & -.08790 & .01972 & -1.27 & 54 & .209 \\
\hline
\end{tabular}

The third additional analysis was done by rerunning the initial regression with only the IFRS variable (SDSTRATG was omitted) in order to exclude the effect of social value and focus only on the relationship with IFRS. An un-tabulated result shows that the coefficient of IFRS was not significant at the five per cent level $(p=.68)$, implying that there is no significant relationship between IFRS convergence and CSD. Alternatively, the regression analysis was rerun using only the SDSTRATG as the independent variable, while IFRS was excluded. An un-tabulated result shows that the SDSTRATG is significantly related to the CSD $(\mathrm{p}=.002)$.

Overall, the results of additional tests confirm the initial results: that the Saudi manufacturing and utilities firms did not respond to IFRS convergence by modifying CSD, while they considered the social value by disclosing more information on CSR. 


\section{Conclusion}

The aim of this study was to examine the determinants of CSD in Saudi Arabia. Specifically, it set out to examine the relationship between IFRS convergence and social values on the CSD of the corporate sector of Saudi Arabia. It is hypothesized that the change in the financial disclosure environment set in motion by IFRS convergence will influence CSD either positively or negatively, depending on whether companies are shareholder- or stakeholder-oriented. On the other hand, companies' response to social values can be a reason for CSD in countries that derive their legislative regulations from the beliefs and norms of society. In such settings, firms tend to establish CSD as a strategic objective to convey corporate social responsibilities activities, thereby enhancing their legitimacy and their prospects for longer survival.

Based on a total of 292 Saudi manufacturing and utilities firms listed in the period of 2015-2019, the current study finds that IFRS convergence is not an important factor affecting the extent of CSD in the Saudi corporate sector. Instead, social values, as modeled using CSD as a strategic objective of firms, have an important role in determining the CSD.

The results of this study extend the literature on the determinants of CSD. Unlike prior studies, the current study not only focuses on the effect of the change in the disclosure environment through IFRS convergence, but it also examines the effect of social forces on CSD. Specifically, the results of this study provide evidence supporting the view that CSD is influenced by social values rather than changes in the disclosure environment in countries that exhibit strong conformity to societal values, such as Saudi Arabia. This study also contributes to methodology by modeling and analyzing the effect of social values on CSD which will add to an understanding of the factors determining CSD outside the shareholder and stakeholder orientation model.

The results have implications for Saudi Arabian regulators that are useful to improve the regulations related to CSD. One avenue suggested in this regard is to upgrade article No. 87 of the CG code related to CSD to be a compulsory article, rather than merely a guiding article. Further, responding to social forces, it is recommended that Saudi listed firms establish CSD as a strategic objective in order that they may be legitimized within the society in which they operate.

Although this study contributes significantly to practice and theory, there may be some limitations. The social values variable is substituted by using CSD as a strategic objective. This procedure provides an indirect measurement for the effect of the social value on CSD, since this study uses a "passive" rather than an "active" concept. Another limitation of this study could be related to measurement of the CSD. Although the current study includes the common dimensions used by other researchers in the literature to measure CSD, there are other dimensions that are not included in this study, which might be a limitation concerning the need for a comprehensive measurement of CSD. The subjectiveness inherent in the content analysis method might also lead to biased estimates. Finally, selecting the sample from only manufacturing and utilities firms limits the generalizability of the result to other Saudi corporate sectors.

Despite these limitations, the current study addresses several issues that call for further examination by future studies. Considering the limitation of using the content analysis method, it is recommended that future research uses survey and interviews to identify the determinants of CSD in order to reduce the bias that may stem from using content analysis alone. In addition, future studies might investigate other CSD dimensions to alleviate the concern of measurement bias. Finally, although the sample size of this study represents more than one-third of Saudi nonfinancial firms listed on TADAWL, which is certainly sufficient to conduct research, it is recommended that future studies increase the sample size to include other service firms in order to enhance the utility of the research results.

\section{References}

Ali, W., Frynas, J. G., \& Mahmood, Z. (2017). Determinants of Corporate Social Responsibility (CSR) Disclosure in Developed and Developing Countries: A Literature Review. Corporate Social Responsibility and Environmental Management, 24, 273-294. https://doi.org/10.1002/csr.1410

Avwokeni, A. J. (2016). Does IFRS Detract from Social Disclosure in Corporate Annual Report and Accounts? Evidence from Nigeria. Acta Universitatis Danubius, 12(5), 82-95.

Barth, M. E., Landsman, W. R., \& Lang, M. (2008). International Accounting Standards and Accounting Quality. Journal of Accounting Research, 46(3), 467-498. https://doi.org/10.1111/j.1475-679X.2008.00287.x

Bureau of Experts at the Council of Ministers. (1992). Basic Law of Governance. retrieved from:

Rule Details (boe.gov.sa).

Bouten, L., Everaert, P., Van Liedekerke, L., \& De Moor, L. (2011). Corporate social responsibility reporting: A comprehensive picture? Accounting Forum, 35(3), 187-204. https://doi.org/10.1016/j.accfor.2011.06.007

Cohen, J. (1988). Statistical power analysis for behavioral science, $2^{\text {nd }}$ ed., Hillsdale, NJ: Lawrence Earlbaum Associate.

Consoni, S., and Colauto. R.D. (2016). Voluntary disclosure in the context of convergence with International Accounting Standards in Brazil. Review of Business Management, 18(62), 658-677. https://doi.org/ 10.7819/rbgn.v18i62.2242 
M. AlShetwi /Accounting 7 (2021)

Donaldson, T., \& Preston, L.E. (1995). The stakeholder theory of the corporation: Concepts, evidence, and implications. Academy of Management Review, 20, 65-91. https://doi.org/10.5465/amr.1995.9503271992

Fifka, M. S. (2013). Corporate Responsibility Reporting and its Determinants in Comparative Perspective - a Review of the Empirical Literature and a Meta-analysis. Business Strategy and the Environment, 22, 1-35. https://doi.org/10.1002/bse.729

Francis, J., Nanda, D., \& Olsson, P. (2008). Voluntary disclosure, earnings quality, and cost of capital. Journal of Accounting Research, 46(1), 53-99. https://doi.org/10.1111/j.1475-679X.2008.00267.x

Frynas, J. G., \& Yamahaki, C. (2016). Corporate social responsibility: review and roadmap of theoretical perspectives. Business Ethics: A European Review, 25(3), 258-275.https://doi.org/10.1111/beer.12115

Hair, J. F., Anderson, R. E., Tatham, R. L., Black, W. C., \& Babin, B. J. (2006). Multivariate Data Analysis, $6^{\text {th }}$ ed., PrenticeHall International, London.

Hsu, F., \& Chen. S. (2020). Does corporate social responsibility drive better performance by adopting IFRS? Evidence from emerging market. Journal of Computational and Applied Mathematics, 37(1), 1-14. https://doi.org/10.1016/j.cam.2019.112631

Igwe, P. A., Ituma. A. I., \& Madichie, N.O. (2018). The Evaluation of CSR and Social Value Practices Among UK Commercial and Social Enterprises. Entrepreneurial Business and Economic Review, 6(1), 37-51.

Issa, A. (2017). The factors influencing Corporate Social Responsibility Disclosure in the Kingdom of Saudi Arabia. Australian Journal of Basic and Applied Sciences, 11(10), 1-19. https://ssrn.com/abstract=3252993

Khan, S., Al-Maimani. K., \& Al-Yafi. W. (2013). Exploring Corporate Social Responsibility in Saudi Arabia: The Challenges Ahead. Journal of Leadership, Accountability and Ethics, 10(3), 65-78.

Li, X., \& Yang. H. I. (2016). Mandatory Financial Reporting and Voluntary Disclosure: The Effect of Mandatory IFRS Adoption on Management Forecasts. The Accounting Review, 91 (3), 933-953. https://ink.library.smu.edu.sg/soa_research/1450

Reverte, C. (2009). Determinants of Corporate Social Responsibility Disclosure Ratings by Spanish Listed Firms. Journal of Business Ethics, 88, 351-366. http:// Link.springer.com/article/10.1007/s10551-008-9968-9

Smith, J., Gouldman, A. L., \& Tondkar, R. H. (2014). Does the adoption of IFRS affect corporate social disclosure in annual reports? Advances in Accounting, Incorporating Advances in International Accounting, 30(2), 402-412. https://doi.org/10.1016/j.adiac.2014.09.015

Smith, J., Adhikari, A., \& Tondkar, R.H. (2005). Exploring differences in social disclosures internationally: A stakeholder perspective. Journal of Accounting and Public Policy, 24, 123-151. https://doi.org/10.1016/j.jaccpubpol.2004.12.007

Weerathunga, P.R, Xiaofang. C., Nurunnabi. M., Kulathunga. K.M., Swarnapali. R.M. (2020). Do the IFRS promote corporate social responsibility reporting? Evidence from IFRS convergence in India. Journal of International Accounting, Auditing and Taxation, 40, 1-19. https://doi.org/10.1016/j.intaccaudtax.2020.100336

Zeghal, D., S. M. Chtourou, and Y. M. Fourati. (2012). The Effect of Mandatory Adoption of IFRS on Earnings Quality: Evidence from the European Union. Journal of International Accounting Research, 11(2), 1-25. https://doi.org/10.2308/jiar-10221 


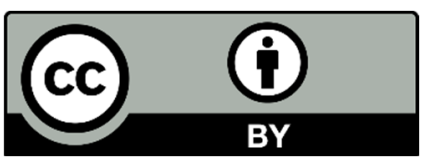

C 2021 by the authors; licensee Growing Science, Canada. This is an open access article distributed under the terms and conditions of the Creative Commons Attribution (CC-BY) license (http://creativecommons.org/licenses/by/4.0/). 